Article Type: Research Paper

\title{
'CHALKING UP THE BENEFITS' PROJECT: THE ECONOMIC VALUATION OF ECOSYSTEM SERVICES IN LEWES, EAST SUSSEX, ENGLAND
}

Wulandari

\begin{abstract}
The economic valuation of ecosystem services has promoted awareness from within the society to both the ecological and economic consequences of biodiversity loss. This has emerged with reference to the debate about its usefulness. This study, however, reviewed the concept of ecosystem services as a discourse within its metaphor about human dependence on the natural world. Some literature, reports or strategic plans, historical archives and websites were reviewed to conduct the sociopolitical analysis of the institutionalization of the concept in the prior review. It depicts specifically the context of the local communities' movement to value the natural capital at the Lewes area, East Sussex, England as part of the programs to decouple 'green payment' from agricultural sector. Based on the collected evidences, this research argues, there have been a similar pattern of the institutional settings towards the environmental protections between changes related to agricultural and urban pressures. Finally, it can be concluded that, the discourse of ecosystem services using the economic valuation process has also been shaped by the elite capture.
\end{abstract}

\section{CITATION:}

Wulandari. (2019). 'Chalking Up the Benefits' Project: The Economic Valuation of Ecosystem Services in Lewes, East Sussex, England. Jurnal Ekonomi \& Studi Pembangunan, 20(1), 27-48

\section{ARTICLE HISTORY}

Received:

January 2019

Keywords: Economic valuation; Ecosystem service; Natural capital.

JEL Classification: Q51, Q57, Q50

Accepted:

April 2019

\section{Introduction}

Ecosystems are essential to civilization, but modernity apparently obsecures their existence. The widespread loss of farmland and water to the urban and industrial purposes, for example, has demonstrated the impact from the human activities which brings up the depletion of natural resources (Daily, 1997, p.2). Understanding this change has become one of the important realms (Chapin, et. al., 2009).

The varieties of documented campaigns and systematic organizations have increasingly been shaped to warn about the alarming rate of the environmental degradation such as global warming, floods, droughts, landslides, and pollution. A concept remaining the essential of human dependence to the natural world is mainly correlated to this change.

The ES concept offers one of the pertinent resolutions for 'the human survival'. The useful part from the concept is the opportunities to 
communicate varying parties about the inclusiveness of the conservation world (McCauley, 2006) - where emanating a sense of stewardship for the nature is necessary. The attracted extension of this concept is inadvertently shaped by interwoven the objectification of the natural world' (Rogers, 1998). The logic roots have framed the environmental degradation as a 'market failure' (Gómez-Baggethun and Ruiz-Pérez, 2011). This expansion is the domains of the environmental economics which have devoted to the methods of valuing the natural world.

Some scholars agree that this concept is a way forward for conservation due to the crisis in the traditional one. It involves wider actors to define the suitable economy for the environmental situation. The utilitarian framing, for example, has taken a part into this concept by the 'use values' in measuring the social benefits of ecosystem functioning which has widely attracted the Western policy maker (Westman, 1977). Some others, however, conversely decide that this concept is another potential tragedy in the conservation history. The 'metaphor of nature as a stock that provides a flow of services is insufficient for the future of the environment' (Norgaard, 2010, p.1219). This could be a disruption in the policy arena which use the available room to maneuver.

Ecosystems, in this study, define as natural benefits from multiple resources rather than a single resource such as fish or tree (Chapin, et. al., 2009). Historical speaking, giving the voice for the voiceless, such as the term 'services' for the natural world, deserve to be more closely studied. The 'services' has evolved into the unprecedented monetary value for the prior non-marketed environment - see example for carbon trading (Carton, 2014). Even though the environmental protection needs to control wisely the quantity of consumption on the natural world, doubt of the kind protection has come since the limit of ecosystems is indefinite.

'The focus on economic valuation of the ES has contributed to attract political support for conservation, but also to promote the commodification of the ecosystem functions' (Gómez-Baggethun, et. al., 2010). It unfold the question as what Caroline Lucas, MP, stated in a debate 'gentleman agree that we need very strong safeguards including in planning system, to ensure that by putting a pound sign on priceless ecosystems such as ancient woodlands we do not inadvertently open the door to their destruction?' (House of Commons Hansard Debates for 21 Oct 2013). This question shows the political attention to be 'a sign of commodification process' as a dilemma in the environmental policy in the UK.

Some literature, that seems promote the reconciliation of the theory and practice, has involved the distribution and efficiency aspect into the schemes using the ES concept. Muradian, et. al. (2010) explain the insight to encourage the knowledge about the ES as the purpose to avoid commodification agenda in the 'steward earns principle' policy which is directly proportionated with the importance of economic incentives. In doing so, obstacles exist due to the complexity of the ecological and economic field. It seemingly needs necessary innovations to tackle the complexities in the provision (Vatn, 2010). The detail of the schemes draws in the institutional settings related to social embeddedness and legitimation of the community empowerment. The setup, eventually, may create the 
high 'transaction cost' as there is the need to sustain the payment for 'the services providers'.

This study, therefore, is particularly interested in how the policy arena can further develop and strengthen the ES concept as a discourse at the UK. It is important since this country is at the second place after the US which have contributed based on the affiliations of the author to the 7985 articles at Scopus that embrace the related concept (Chaudhary, et.al., 2015, p.29). The analysis of the discourse will focus on the institutionalization process of the ES concept using a time frame from the prior review to enable recognition of social and political issues (ibid; Den Besten, et. al., 2014).

The analysis, however, involves aspects from the controversy on economic valuation of ES. The political critiques will be presented as the substantial part. The aspects are 'particular institutional setup and expansion of pricing into previously non-marketed areas of the environment' (Gómez-Baggethun and Ruiz-Pérez, 2011, p.613). Based on the collected evidences, I conclude a similar pattern of the institutional settings towards the environmental protections in between changes related to following: 1) agricultural pressures, and 2) urban pressures.

The following sections provide the incorporation of the ES concept in terms of the 'neoliberal turn' events in the societal interactions. Firstly, it emerged on the agricultural policy in the UK which has transformed the state-supported policy AEP into the 'PES talk' approach (Porter et. al., 2014). Secondly, the innovation on the institutional setup on the PES preference for results-oriented payments in policy documents such as the Natural Environment White Paper, Defra 2011 (Lockhart, 2015). Lewes 'Town to Down' initiative assessing the value of ES to local communities is the specific case in this study of the White Paper implementation. A documented film provided by the CUB project from related web archives will be provided in transcriptions to review the potential benefit for the housing builders through the initiatives of the environmental protections. Finally, I argue that the discourse of ES using economic valuation process has also shaped by the elite capture.

\section{Research Method}

Implementing the ES concept has transformed as an ambivalence in the conservation world. Armsworth, et. al., (2007, p.1384) highlight preliminary questions for the research plan implementing the concept such as 'what decisions regarding the ES is the science intended to inform? What opportunities are available to change the provision and consumption of those services?' They assert, as the respond, the ES science should improve the insight about the fundamental links between the natural world and human well-being.

Early 1980s was the time where the environmental issues academically received attention and the term of ES was first used (Chaudhary, et. al., 2015). Specifically, the focus has intertwined with the landscape changes. Those are not only an anthropogenic pressure but also the growing notion into something that related to 'the process of wealth creation 
factors economically called natural capital and social capital (Costanza, 2003). The economic logics stated those two types of capital as the production factors.

'A core idea behind markets is to establish competition among agents to foster efficiency' (Vatn, 2010, p.1246). Whilst, the role of the communities' governance provides the solution to reduce the transaction cost 'by increasing the necessary trust and engagement into the community' (Vatn, 2010, p.1250; Vatn, 2002). It is today that the environmental protection has mainly one focus in terms of the direction of development. Sharp and Richardson (2001) mention, as a discourse in the environmental policy approach, it would bring about the social change notion where institutional structures and communication as the causal factors.

The jargon bioregionalism from the deep ecologist show the same pattern in the needing to engage people into the new way of living. 'This is the idea of people living in harmony with the land and the seasons' (Chapin, et. al. 2009). This is a principle for sustainable society that has the similar requirement with the notion of the ES concept. Even though there is a different part of those practical movements. ES concept which involve a 'cosmetic solution' has promoted a collaboration within actors until the global scale; Bioregionalism or the dark green one in the context of the lifestyle, however, has promoted the decentralization mode where 'small is beautiful'.

The effort in this study is more to analyze the elite capture as the social and political issues at the policy arena mentioned by the independent media in the UK. Those are restricted only to the mode of how political arena tackle both to the hunger and living - food and housing necessities -, and the environmental protection.

The analysis adapts to use discourse-centered analysis using institutional time frame from the prior review (Chaudhary, et. al., 2015; Den Besten, et. al., 2014). The general time frame of the growing shape of the ES concept are as followed (Table 1).

Table 1 The Evolution of ES Concept

\begin{tabular}{|c|c|c|}
\hline Year & Events & Evolution concept \\
\hline Pre-1997 & - & Early academic conceptions of ES \\
\hline 1997 & $\begin{array}{c}\text { When PES was first adopted } \\
\text { as a national scale policy in } \\
\text { Costa Rica }\end{array}$ & $\begin{array}{l}\text { Expanding economic and policy } \\
\text { interest in ES }\end{array}$ \\
\hline 2001 & The launch of MEA & Uptake of ES concept by global actors \\
\hline 2005 & $\begin{array}{c}\text { The release of MEA synthesis } \\
\text { report }\end{array}$ & Global reporting on ecosystem services \\
\hline 2010 & $\begin{array}{l}\text { When agreement on IPBES } \\
\text { was reached, followed by it } \\
\text { establishment in } 2012\end{array}$ & $\begin{array}{l}\text { Institutionalisation of an } \\
\text { intergovernmental body on } \\
\text { biodiversity and ES }\end{array}$ \\
\hline
\end{tabular}

Sources: Chaudhary, et. al., 2015; Den Besten, et. al., 2014; modified 


\author{
Wulandari \\ 'Chalking Up the Benefits' Project: The Economic Valuation of Ecosystem Services...
}

The doubt is about the instruments of power upon the pricing notions of the natural resources arising from the reflection towards sustainable society. Literally, 'dark green movements' have the goal to be independent from a mode of centralized authority such as 'a legislative framework giving access for the government to the continuing domestic sphere' (Chapin, et. al. 2009). But the economic valuation of the ES has promoted access to a global scale. It configures the contrast in the expanding trend from the initial purpose of the ES concept.

The following sections will put more effort to emphasizes correlated events within the societal interactions in the history and contemporary.

\title{
Result and Discussion
}

\section{State-supported for centralized authorities and trade impetus}

The War World II is the deadliest tragedy in the humanitarian history. It followed by the remarkable cooperation regarding the negotiations of the earlier European integration during the cold war. The geopolitical rearrangements of the European dynamics were fraught with the decades of diplomacy (Ludlow, 2005). The Contemporary European History cover the questions ranging from Britain's foreign policy first attempts to engage with the Six in early EEC, to American's hegemony towards the goal of European political union, elaborating via the first European treaties and the initiation of CAP.

\section{The history of earlier European integration}

Charles de Gaulle, was adopted the first veto in the Rueff Plan and the FTA for stabilizing the French economy (Lynch, 2000). The December 1958, renewing protection and foreign indebtedness had have facilitated the French economy in the EEC and the GATT - it was the time where the British proposed to set up FTA. The French's failure to tackling the deficit in the balance of payment has stated as the reason behind the British political economy 'to keep France out of the Common Market' made the FTA seems more attractive (Ibid, p.115). At that time, both are having different imperial preferences: French within the Physiocrat belief retained the agriculture products engagement for the more specific market area; England disagreed with the agriculture part and proposed wider zone for the international trade.

Changes in commercial policy was what a country necessary do in the name of security (Schenk, 2002). Thus, in between the 1955 and 1963, trade agendas have become the impetus of the economic integration probably the most remarkable one. The fundamental policy reversal contains the negotiation 'from Britain's refusal to take part in the common market project launched by the Six of the ECSC at the Messina conference to Prime Minister Harold Macmillan's effort to negotiate entry into the EEC' (Schaad, 1998, p.39). It was due to the growing continental market situation that could endanger the Britain economic situation for being outside the European market. This reversal decision, moreover, involved its alliances with the United States and West German. 


\author{
Wulandari \\ 'Chalking Up the Benefits' Project: The Economic Valuation of Ecosystem Services...
}

Beyond the reversal policy from French and Britain, the aimed at promoting French agriculture exports had been the French's motivation in rejecting the FTA which was fewer prospects in agricultural exports than the EEC's common market (Warlouzet, 2011). Moravcsik (2000, p.27) writes De Gaulle's remark about the European identity, 'political will is the spirit behind economic unification', purposing to limit the EEC member only for the Six. Toward this Gaulle's proposal, American government observers realized that these political plans for Western Europe were aimed against US influence 'on the continent and in the Atlantic alliance' (Giauque, 2000, p. 108). The FTA once facing the failure in the $1956-1958$, this failure led the common market of the EEC to surpass the FTA's technical and political aspects including the integration of cooperation in the agricultural sector.

\title{
Mobility towards polarity
}

The historical events bring the market impetus within the growing of the environmental politics. It has ironical events which embedded the powerful hegemony of the global 'polarity' (Patel, 2013, p. 650). A history of the European integration has formed through the political struggles in between hegemonic forces from the United States and the Soviet Union. The European Union thence is the formulation in creating the new force outside those two mentioned (Giauque, 2000). Those such a competition have contributed into the new institutional setup during a heated international affairs.

In the 1982, 'European Conference of Postal and Telecommunications Administrations (CEPT) has become the postage stamps on a European theme at the twenty-fifth anniversary of the Treaties of Rome commemoration' (Patel, 2013, p. 649). Historical archive represented this ironic twisted momentum highlighting a non-governmental organization movement to step in telecommunications strategy. It is the 'sectors requiring urgent action' prior to the Treaties of Rome where the Six disagreed. Although the CEPT had a position of outside the Treaties of Rome, several states member would facilitate it. It came up into the explanation why Dutch, French, and Italian stamps looked quite different, whilst, the implementation of the CEPT encompassed a wider range of states member than the European Communities (EC).

In 1989 to 1991 (post-cold-war period), Gaullist vision for the more autonomous from the US's influence of Western Europe has provoked the emergence of the European identity - where Europeans applied to the civilization at the same continent. 'The failure of the confederation project reflected the at least partial, and temporary, failure of the vision of European architecture which Mitterrand, after de Gaulle, had tried to promote' (Bozo, 2008, p.412). It had seen in 1988. During the period of Mitterand as the French president, Moscow visit on 25th November clearly was the strategy to attach with Gorbachev's 'common home'. The visit was beyond the need for more pragmatic and concrete cooperation in the European, naturally transcend the east-west's borders. It notes the environmental and technological exchanges associated with the certain aspects of the Soviet Union 'Eureka' project as the main consent towards the futuristic projection. 


\author{
Wulandari \\ 'Chalking Up the Benefits' Project: The Economic Valuation of Ecosystem Services...
}

The challenge has come across the unrested interconnections. The 'theme of Europe is so ideologically plastic that it can fit effortlessly into the discourse of any national political party' (Bruneteau, 2000, p.257). Therefore, an international and regional organization might be 'established to seek solutions no other form of institutional setting provides' (Patel, 2013, p.670). The adjustment toward the environmental protecting act, however, still has the possible influence towards the solution of this global 'polarity'.

\title{
Common agricultural policy
}

The history has captured the order onto the agricultural reform coming from the controversial arrangements. The CAP assertion has also attributed to changes as the negotiations provides power and control through the European budget (Jackson, 1993). The European integration should be a 'discursive' which 'reminds the heterogeneous and unequal encounters can lead to new arrangements of culture and power' (Tsing, 2005, p.5). Tsing's analogy demonstrates that the inter-connected form can be described as the roads image to conceptualize how the global collaboration works. Roads in this image explain of how efficient and easy the pathway is giving to the motion, but in doing so they are also the limit of where is the movement goes.

CAP 'has been the European Union's most expensive integration consuming a substantial proportion of the EU budget' (Ludlow, 2005, p.347). The tariff war combined in this earlier European integration was one reaction from Britain government towards the French Gaullist official's hostility in 1958 to 1969 (Warlouzet, 2011, p.431 - 433). The competition proposing the Common Market and the FTA schemes was the circumstances attributing to the time when CAP was born (Warlouzet, 2011; Lynch, 2000). The political strategy made EEC membership for the UK had to wait for the common market project of the Six including the CAP well-established (Schaad, 1998).

The CAP's policy specifically was born in the midst the dynamics of economic integration of the EEC. Ludlow (2005) starts his attention to the political analysis with one of the extended political science of the European Union, Andrew Moravscik. The analysis highlighted the political situation during the cold war studies which attract vast attention from the historian responds. As what Moravcsik (2000) writes, profound origins of the CAP at the early EEC is where the political organization thrived in creating the new single identity through the European Union.

The origin of the constitutional support for this policy could be summarized in the foundations of European Law (De-Smedt, 2012). In 1950 - 1957, those dynamics in laying the foundations contain a strict and literal sense based on the Treaties of Rome interpretation from the ECJ. Those senses come from the ambiguous cases in using the extension of the national sovereignty. From 1958 to 1968, 'despite the vagueness of the Treaties' commitment to an agricultural policy and the unpromising precedents of earlier attempts to integrate Europe's agriculture, there are political factors that made the CAP's birth possible' (Ludlow, 2005, p. 347). CAP is part of the power bargain in the history for the agricultural sector. The December 1964, the level of cereal price has become the 


\section{Wulandari}

'Chalking Up the Benefits' Project: The Economic Valuation of Ecosystem Services...

suggestion from the commission remarked on the harmonizing of the 'common price system which vital to the operation of the CAP' (Ibid, p.351).

As outlined in Article 39, CAP was 'to increase agricultural productivity by promoting technical progress and ensuring the rational development of agricultural production and optimum utilization of the factors of production, in particular labor' (The Treaty of Rome, 1957). The policy was to give the incentive for the farmers/landowners who were needed by the civilization to produce adequate livestock for the 'alarming rate numbers of the human population' (Dobbs and Pretty, 2008). But critiques existed in the national scale afterwards.

\section{The discursive today and historical analysis}

The current structure of farm subsidies epitomizes the British government's defining project: capitalism for the poor and socialism for the rich (Monbiot, 2013).

Farming has also produced the ecosystem functioning in terms of the 'conventional services' providing by the natural world to promote food industrialization. The wealthy farmers gradually has the privilege to get the subsidies. Trade and environmental protections have conflicted in 'the moral argument that no one should go hungry' (Constanza, 2003). Elite capture, in farming context, has obviously shape the political alignment.

CAP is the power bargain that promote the control of hegemony through the recent controversial subsidy for farming. The history has highlighted that UK has been excluded at the initiation of the CAP pertaining to the avoidance from the US hegemony on the early European Integration (Giauque, 2000, p. 108). Therefore, the domination of the ES concept as a discourse at the US and UK (Chaudhary, et. al., 2015) has probably the continuation on the global polarity. The growing market-supported on the ES concept such as PES could be a response to the disruption on the environmental situation. But it should not separated from an insight of the production control in the global scale.

\section{Agricultural pressures and PES}

Farming is for sale and trade purposes. Recently, CAP is one part of policy to understand the PES as the 'neoliberalism challenges' on the AEP which is the state-supported on environmental protection due to the disruption on the farming (Dobbs and Pretty, 2008). In terms of the UK member status at the EU, the CAP has been the legacy of the generalization efforts end up with the making of the friction juxtaposing the insight from 'the global connection' (Tsing, 2005). The AEP, however, has seen as the traditionally more state-centered while the 'PES talk' has opened the access of 'adaptive opportunities' for private sector in the policy communities for the environmental protections (Ibid). It involves the wide spread notion on the sustainable society.

The events on the societal interactions focus on the 'production metaphor' and the future of CAP which implies the necessary attention beyond the limitation from the natural world. The conservationist has identified that if human dependence (in the production 
activities) on nature 'becomes widely recognized, society will demand greater environmental stewardship' (Armsworth, et. al., 2007, p.1383). This is to say where the ambivalences on the conservation world have the effect on the ES concept. Meanwhile, environmental issues in the political arena has also been an idea since the growing threat of nuclear war (Chapin, et. al. 2009). Policy arena has been attracted to the use of environmental issues in a political approach.

\section{Leaving behind the agricultural intensification}

'In the EU, the driving force behind agricultural intensification has been the CAP, which simultaneously supports greater productivity and inhibits agricultural extensification' (Donald, et. al., 2002, p.167). They noted that the CAP implicitly provokes the livestock's providers in industrial scale within the two ways to protect the member states' producers. Firstly, market intervention: the EU keep the international trade of the agricultural product's prices high and stable. The EU has the role as the buyer in the market due to this function. Secondly, market stabilizer: the EU also buy the excess of production. These mechanisms increase the burden on the EU budget for the storage cost until the products competitively sell on the global market. To support the operation, the less international trade barriers need to be certain and levy on cheaper imports.

The CAP's continuation faces new stage that is about tackling the environmental impact caused by the industrial agriculture. It has provided the farmers in the member states with the increasing income; access to the most modern agricultural technology; and received indirectly greater benefit from the raising of land value since there are also increasing demand on it (Donald, et. al., 2002). It brings the root of history from the era feudalism to capitalism in 'the deepening rupture in the nutrient cycling' (Moore, 2000, p.123). The opportunity from the agri-food exports, moreover, still guarantees the future profit. From the monitoring agri-food trade of European Commission (2017) noted, 'The monthly value of EU agri-food's exports rebounded in May 2017 and reached a value of EUR 11.5 billion, which is EUR 923 million (+9\%) higher than in May 2016, and 15\% higher than the 4-year average'. This statistical number in other words show that agricultural industries still have wide opportunities to keep its operation in the international trade.

On contrast, those livestock sectors with the level of industrial scale is still socio-political compelling despite there is the need for the 'urgent action' in 2006 for the environmental issues which is explained by the LEAD initiative in the landmark report Livestock's Long Shadow. These sectors are important since 'it accounts 40 percent of agricultural GDP and employs 1.3 billion people' (Steinfeld, et. al., 2006, p. xx). It remains the political inertia despite the structural changes (in the degradation way), for instances, geographical changes ('bad' environmental quality) and social exclusion of the smallholder farmers in the farming subsidy's schemes.

Some believe that it has increasingly necessary to leave behind the intensification practice. Plerson in HuffPost UK, for instance, concludes that the 'industrial agriculture' as the 'failing industry'. The suggestion is that the government need to stop supporting it; and need to start making it greener. The fact shows that the environmental impact from 


\section{Wulandari}

'Chalking Up the Benefits' Project: The Economic Valuation of Ecosystem Services...

animal's agriculture is still being ignored as 'The Paris Agreement, signed by 196 countries, omitted any mention of livestock, agriculture or animals across its 31 pages' (Plerson, 2017).

There are consequences from the such farming practices. Some publications revealed the evidences to criticize the effect from the prior food cycle. It might be similar to the message from the UN and IPES FOOD report, the 'world needs to move away from the industrial agriculture to avoid ecological, social and human health crises' (Plerson, 2017). Whilst, the health issues of the food industry also support the raising awareness about the farming in industrial scale issues (Figure 1).

The more elaborate solution, however, will inadvertently raise the question about how to create the political incentives towards the proposed shifting onto the less intensification agricultural system. This could be the challenges of the political inertia in terms of the food industry. Sullivan $(2012$, p.199) mentions, 'a key feature of the contemporary capitalism includes the penetration of finance into everyday life'. It mentioned that the 'economic profit and political utility' has highlighted the paradox in the financialization process in the conservation world. This could be an incursion towards the increasing need for the healthy environment.

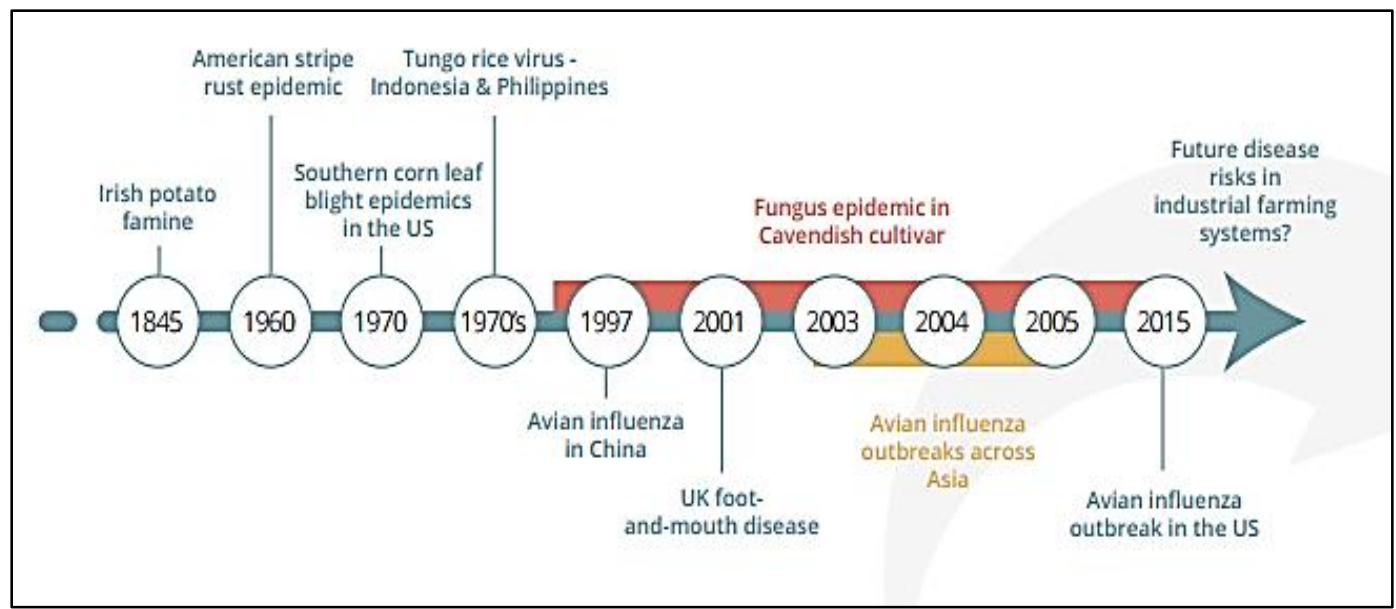

Figure $1 \mathrm{~A}$ Timeline of Disease Outbreaks in Highly Specialized of Farming's System Source: IPES FOOD $(2016$, p.3)

\section{Insufficiency of the conventional policy on agri-food}

AEP have been introduced as the integration of environmental concerns in the agricultural policy since the 1992, while the global market practice in the food production keep continuing. The 'potential exists to restructure EU support for agriculture to decouple payments from productivity and reward farmers for making environmental improvements to their land' (Donald, et. al., 2002, p.167). Eventually, changes are provoking another type of financial scheme through the AEP to protect the environment, where most of the farmers need better contacts with local conservation organizations - in order to participate (in the South East England case) (Lobley and Potter, 1998). 


\author{
Wulandari \\ 'Chalking Up the Benefits' Project: The Economic Valuation of Ecosystem Services...
}

The doubt has particularly rised into the political maneuver which defines the value of ES as an economic framing stage on the commodification process. The sense of 'bringing together the sustainability' has been probably still in the range of the neoliberal system which 'based on the ideas of reducing the power, reach and interference of government, and giving industry greater freedom and less red tape' (Brockington, Duffy and lgoe, 2008, p.1). The industrial agriculture thrives followed by the green 'credentials' to promote the farming practices with the more adaptable to the higher level of the environmental stress (See e.g.: Natural England, 2008; Chaplin, et.al, 2017). 'A cosmetic solution' has involved wide range of changes in economic production to bridging the gap in between the economic growth and environmental protections.

The today's subsidy budget for the farming schemes seems problematic. There are still hope to find 'reasonable' price for the cereals and cereal products in the supermarket while confronting the failure of the ethics in providing the outcomes from the natural world. Cereals 'represents one of the most profound anthropogenic changes to Europe's landscape and wildlife habitat, which encourages the pandemic effects of agricultural intensification that have been demonstrated on bird declining population' (Donald, et. al.,2002, p. $168-169)$. The review is that the less support for the intensification of the farming practice, the more socioeconomic and socio-ecological benefits would arise which can support the EU enlargement.

The 'ecosystem functioning' has been the reason for the policy makers to allocate the budget for the conservation world. The extinction of one specific animal or plant that reduce the diversity in the natural world has signalized the ecosystem functioning at the alarming rate (Naem, et. al, 1999). It probably does matter to pay attention to the ecosystem services afterwards - 'the benefit that human gets from the ecosystem functioning' (MA, 2005). AEP, the state-supported projects for the environmental protections, has a gradual changed its approach.

\title{
PES influence on the policy arena
}

Some of the conservation's practitioners have ignored the directions and procedures of the environmental improvement including the ethics and aesthetics in conservations (McCauley, 2006). Incentives are probably still focused on the income values through the financial scheme in preserving the ecosystems; which ignore the animal rights (AF news agency, 2016); encourage the overgrazing (Theobald, 2000); promote 'commodity fetishism' through the payment for ecosystem services agenda. Kosoy and Corbera (2010, p.1234) suggests, this fetishistic of PES implicates 'on the way nature is perceived, humannature interactions are constructed through monetary values and how unequal social relations are reproduced'. It is as encapsulated on the following:

Swanbourne Home Farms, run in partnership between the minister's in-laws, Baron and Baroness Cottesloc, brother-in-law Thomas, and cousin Richard Brooks, has been given $€$ $1,517,535$ over a 10 -year period in funding from the $\mathrm{EU}$. It has also been the recipient of grants understood to be worth tens of thousands of pounds from Natural England (Muir, 2013). 


\author{
Wulandari \\ 'Chalking Up the Benefits' Project: The Economic Valuation of Ecosystem Services...
}

The media gives the data in the field of politics that there is a 'double counting on the funding for environmental protection (Gómez-Baggethun and Ruiz-Pérez, 2011). It is an important problem in the body of the bureaucracy called the least priority of the environmental policies for the sake of nature. It is imperative to provide the collection of the emerging discourses from the environmental justice provision in the sustainable development project (Taylor, 2000; Agyeman, 2001, 2002; Agyeman and Evans, 2004; Agyeman, Bullard, and Evans, 2010). It revealed the problem of injustice within the societal interaction.

It has introduced the UK Defra's Ecosystem Approach Action Plan (Defra, 2011) as the 'introduction of market logic into AEP'. The meanings actors attach to it is quite broad involving farming group and environmental NGOs.

PES approach has the prominence effects on the AEP. The efforts to decoupling the green payments from the agricultural sector also can be seen through the Defra White Paper on the natural environment (Defra, 2011). It is one of the commitments in the body of government to enhance greater business involvement in ES commissioning and funding with 'proof of concept' role. The focus of the green payment is now progressing to another sector outside the agricultural pressure.

\title{
Decoupling green payment from farming: urban pressure and PES
}

Another highlighted change in this study is the urban pressures. The CUB project (http://www.lewes-eco-nomics.org/projects/cub/) regarding the use of ES concept in the effort has setted up to raise the awareness for the valuing the natural capital process using the societal perspectives. It is one of local project arising from the Defra White Paper. It also has the linkage to the neighborhood plan (http://www.lewes4all.uk/) - the local government led to the future of the county area [Transcription: 205]. This section examines beyond the more social inclusion process thrives in the way of 'the nature gain going local workshop process' [Transcription:63]. The political aspects has the intersectional structure through the wider business involvement from Defra and the local development goals through the housing crisis in the Lewes area.

The use of ES concept in the local action has seemingly created the down-top policy mechanism related to the socioecological relationship in the protected area, South Down National Park. It is the provision on the economic values of the nature based on the people perspective in line with the framework "proof of concept' role. The evidence to show 'how valuable these environmental services are to people because the scarce public budget must be spent on their protection' (Mendelsohn and Olmstead, 2009, p.328). But the limited continuation of the Defra White Paper is exist, for instances, the biodiversity offsetting in the UK context which more to fulfil the administrative duty (Lockhart, 2015). The housing builders, from that case, has another role to get the benefit from the such policy. 


\section{Wulandari}

'Chalking Up the Benefits' Project: The Economic Valuation of Ecosystem Services...

\section{Lewes and the spirit of independence}

Lewes is the county area that serves a rural area, manufacturing towns and farming communities situated in a protected area of the South Downs National Park. It is the area that valuable to attract the tourism business (Woodland and Acott, 2007), such as, a national park with a strong recreational atmosphere; River Ouse commemorating Virginia Woolf; seaside of the potential tourism area; and the attractive bonfire tradition. The heritage and modernism values fuse into this commendable land (the welcoming atmosphere characterized by industrialization, rapid social change, urbanization and advance in socio-ecological science with skeptical critiques to the newcomer of the materialist culture).

"We will not be druv!" is 'a local dialect which asserts that Sussex people have minds of their own, and cannot be forced against their will' (Simpson and Speake, 2009). 'Druv' is a dialect variant of drove (Ibid). 'The Battle of Lewes between King Henry III and the barons forms part of the town's proud story of its role in the development of democracy' (Lewes Town Council, 2017, p.10). This history of the tradition of independence in the Lewes area could point out the society's character which showing the enthusiasm to speak 'this is what we want' [Transcription: 204].

Lewes has the remarkable movements toward their local environment in terms of the support from its people. For example, the representation for its efforts in raising the awareness on the impact of the global market for food into the society is captured in the Lewes Pound movement. It is one of influential movement that becomes the root of the CUB project initiation under the umbrella the Transition Town Lewes (TTL) (https://www.transitiontownlewes.org).

The dedication from the Lewes Pound to the practical context might be radical in the socio-economical dimension confronting the pressure on consumers' dependency on the global market of food. It highlights the attention to the local economy which brought the local currencies (https://www.thelewespound.org/) idea to boost local spending on the local economy, helps cut $\mathrm{CO} 2$ emissions by changing the consumption pattern such as from global product into local product which were approved by dozen of environmental activists in the Lewes (Bates, 2008). 'Findings also suggest that complementary currencies can be an effective tool for building resilience and aiding the transition towards more sustainable systems of provision and consumption' (Graugaard, 2012, p.258). From the Lewes Pound practice, we can determine the spirit of independence for the Lewes society to face the climate change and peak oil situation.

Maintaining the monetary strategy, the Lewes Pound collaborates with not-for-profit social enterprises, such as Common Cause Co-operative (http://www.commoncause.org.uk) established in 1991 and (http://lewesfoodmarket.co.uk/) established in 2010. Strategies are involved with the encouragement for the society to enjoy the nature through food growing projects and supporting the local food from the local economy in Sussex. At this point, it is necessary to bring the collection in the practical context of the local societal dynamic within the revolution of the ES concept. 


\section{The CUB: nature's benefit and social inclusion}

The Lewes Pound, with the local economic context, has provoked the continuation of the social interactions within the CUB, a project at a community group namely Lewes and Ouse Valley economics group. On 27 April 2011, the local group (operates under the umbrella of TTL) successfully held a workshop discussing 'what benefit we get in the local community from the local environment, how local enterprises use those ES and how to make the communities more resilience' [Transcription: $91-95]$. Thus, valuing the economic measurement for nature is the part of the workshop discussion. They use the map to visualize the place and emerge the description of their experience of nature's benefit they get from a certain area [Transcription: $96-103$ ]. The local communities has virtually shown the enthusiastic atmosphere.

The importance of the project has also been described in the news. The Lewes Pound in here has the role for investment in the understanding of the local ES (Transition Town Lewes, 2011). It can be a tenacious construction on the interdependency among the local communities based on the prior coordination in raising the awareness of the climate change and the local economy using complementary currency. The Lewes Pound articulates the local pride to alter the independence culture of the Lewes society. It exemplify that the social capital has already existed within the community.

The CUB project provides the interactive discussion which gives the Lewes Pound a position as the medium for 'capacity to aspire' (Appadurai, 2004). This local group project adopts the term 'naturegain' in their introduction rather than what scientists' usually define as 'ecosystem services'. The orientation to the future is to find the most important natural area in the Lewes for the society, and make a partnership with the local organization to understand the services that provided by the ecosystem function. Since the existing local activities consisting of environmental campaigners, the ability of the local community groups appealing to meet the idea of natural environmental stewards need the encouragement to 'value their surroundings' (Brockington, Duffy and Igoe, 2008, p.87). In the conservation world, this partnership is never straightforward.

There are two points attached from the video documentation as the CUB's final outputs to explain the partnership with the local authorities, Lewes Neighborhood Plan Steering group - in a proposed plan for the local authorities using the ecosystem services approach (Tingle, 2015). Firstly, local group maintain 'the ecosystem services going local workshop' to engage the local community groups 'to put themselves into the landscape and experience the benefit that ecosystem provide'. "Here was a contradiction: high profile publicized 'participation processes' on the one hand, vertical control over project delivery on the other' (Mosse, 2004, p.655)". However, it approximately took time for four years since the first workshop exist (April 27th, 2011) until the documented video published (June 24th, 2015).

Secondly, the CUB purpose the inter-social interaction to provide a definition of how the human life along with the Lewes' landscapes both the land use and the land management. 


\author{
Wulandari \\ 'Chalking Up the Benefits' Project: The Economic Valuation of Ecosystem Services...
}

The messages from this workshop are to give people the space to speak, mapping their knowledge about the environment and documented it as the output.

What we can see the landscape we are living is a life with always connections, we value map connections with four different enterprises. If you imagine every enterprise, every household. This entire map would be covered in our strength. We are living within those connections. Here we are all these people up here while this stuff is going on. This is happening around, it is not just abstract concept ecosystem services' report from the UN. This is stuff going on as we speak outside this door, inside this room [Transcription: 177 185].

With the increase of the local pride, the CUB has the role giving the dialogue for the discourses in the socio-ecological relationship, how the society feels about their landscape. In this case, the ecosystem services framework legitimates the human dependence on the ecosystems functioning where measuring the nature value is one of the keys for the policy makers in making the decision (Hirons, Comberti and Dunford, 2016). Ecosystem services concept is the lexicon in this action through the pedagogical procedure. It has the plan to continue in $\mathrm{BOB}$ project, but it has not shown until years after the plan.

\title{
Ecosystem services concept and multiple partnership of the CUB project
}

The CUB project has involved in a partnership of the South Down Way Ahead Nature Improvement Area funded by Defra via Natural England. 'Conservative-Liberal Democrat Coalition government proposed the natural environment white paper in 2011' (Lockhart, 2015, p.337). It has related to the ambitious strategy for Biodiversity 2020 (Defra, 2011; 2013). The Nature Improvement Areas is 'the first natural environment white paper in nearly 20 years' (Vidal, 2011). It was quite attracting where around 15,000 people and organizations asked about this white paper to the governmental body.

The another partnership in the CUB project has shown the anthropogenic pressures still have a role in a local movement using the ecosystem services concept. The 'government introduced the opportunity for local communities to prepare neighborhood plans through amendments to the Town and Country Planning Act 1990 and the Localism Act 2011, and the Neighborhood Planning (General) Regulations 2012' (Lewes Town Council, 2017, p.5). Meanwhile, the CUB project seems to be a legitimation of the 'environmental friendly' in the plan focusing about the spatial policy. As the result, hundreds of the additional housing units in the Lewes (one of the largest settlements area in the South Down National Park) is in the draft of a local government proposal (See Porter, et.al., 2014). It is societal interactions that have apparently spoken for the natural world.

The CUB partnership could be a result from the economic framing stage at the commodification process (the continuation of the valuing natural capital). It has shown the multiple purposes. Firstly, it has been a support for the local economy at the beginning (the roots since the Lewes Pound campaign in 2008). Secondly, a partnership with South Down Way Ahead Nature Improvement (where sympathetic actors such as the project officer embrace to provide the partnership project). Thirdly, the draft of a proposal for the spatial 


\section{Wulandari}

'Chalking Up the Benefits' Project: The Economic Valuation of Ecosystem Services...

policy has launched through the neighborhood plan partnership. In some degrees, the project has provided more to the human sake, rather than the stewardship for the nature sake.

So we turn for relief to Natural England, the official body whose purpose is 'to converse and enhance the natural environment'. Whoops. Its new chair, Andrew Sells, a major donor to the Conservative party, made his fortune in housebuilding, the industry most likely to benefit from biodiversity offsetting (Monbiot, 2014).

The independent media has shown another type of elite capture in the environmental protection projects in the UK. Asymmetric power seems coincidental with the multiple partnership in one of the example projects. It promotes privatization of the land use for the household sake.

\section{The evolution of ES concept and socio-political issues at UK}

Table 2 The evolution of ES concept and socio-political issues at UK

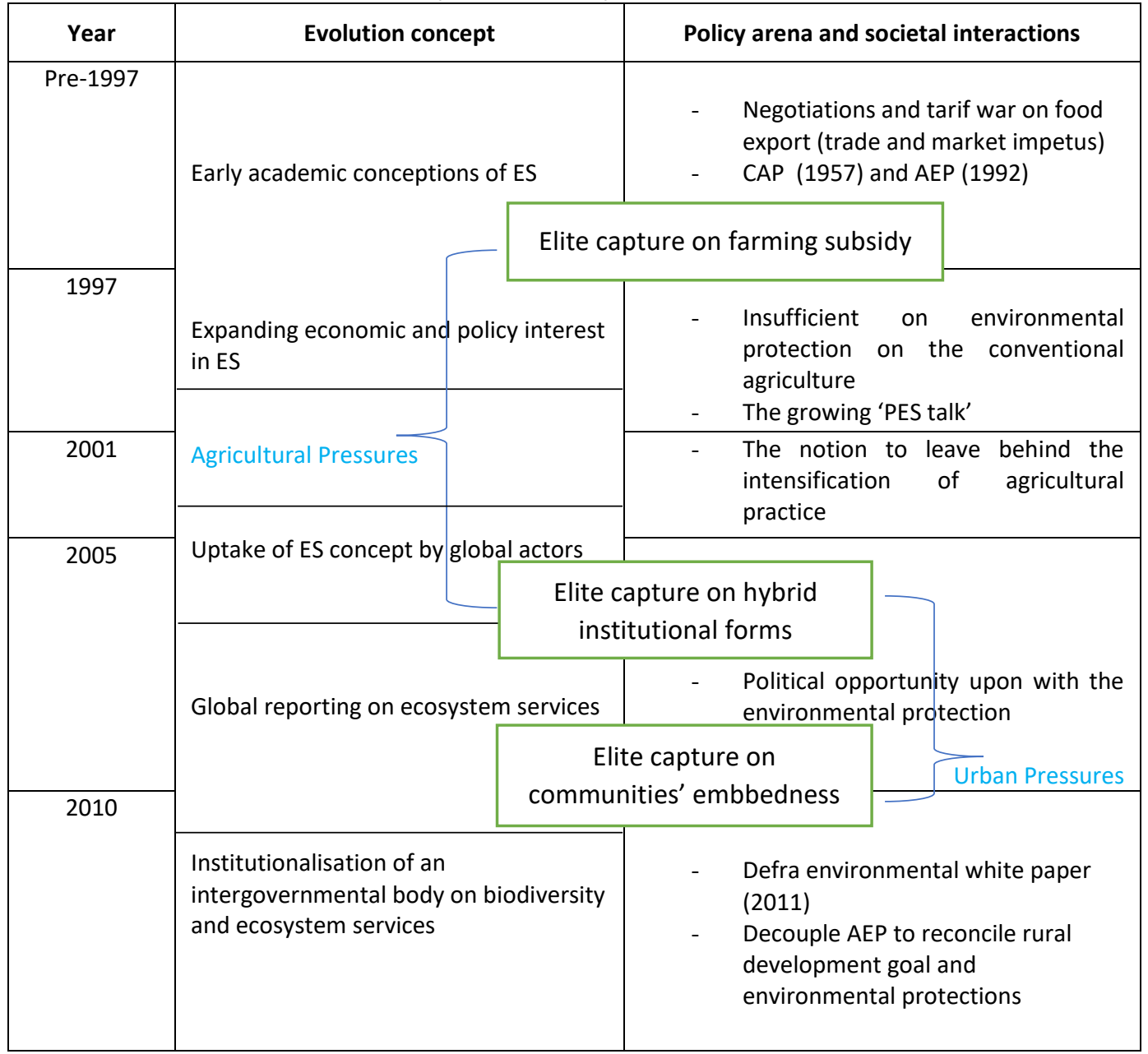


The ES concept evolution has provoked more to create the payment schemes such as PES in the policy arena. Muradian, et. al. $(2010$, p.1207) argue 'that there is instead a greater need to develop local and regional institutional frameworks that can cope with complexity and diversity, and that can integrate PES within existing regimes of rural development and other policy instruments for environmental protection'. This is in line with the result from this study. The dominance from the market approach can be seen at the how PES challenges the AEP where eventually Defra environmental white paper (2011) arised as the part to decouple the 'green payment' from agricultural industry. But the government should not 'forget' that it did promote privatization of the land use.

PES creates another actor in the business-centered politician rather than enhance the close relationship of human and the natural world. The elite capture beyond the PES is not only happen in the developing country. This study shows that the elite capture has also existed through the conceptualization of the ES concept at the UK context. It starts from the subsidy for farming (Monbiot, 2013); 'green payment' in AEP for agricultural pressure (Muir, 2013); and in the effort to tackle the urban pressures (Monbiot, 2014). I argue that it tends to show the similar pattern.

\section{Conclusion}

The exponential attention on the ES concept has the extension to the economic valuation of the ES (Gómez-Baggethun and Ruiz-Pérez, 2011). It certainly promotes the commodification process at the UK as well - as it has been seen in the political debate (House of Commons Hansard Debates for 21 Oct 2013). It shows the correlation on the evolution of the ES concept from the prior review about Institutionalization of an intergovernmental body on biodiversity and ecosystem services (Chaudhary, et.al., 2015, p.29). It is the marked evolution of the concept which focusing on the gap in between the policy and the practitioners.

This study has contributed to the prior review about the evolution of the ES concept in the political arena and the societal interactions within the UK context. The UK in particular has the intersectional relation among its position as the member of EU and the growing attention of the discourse firstly at the US. The key issue is that the possibility of the continuous global polarity on the international trade system on the notion of the environmental protections. The domination of the ES concept as a discourse at the US and UK (Chaudhary, et. al., 2015) has probably the conspicuous explanation since the history has highlighted that UK has been excluded at the initiation of the CAP pertaining to the avoidance from the US hegemony on the early European Integration (Giauque, 2000, p. 108). The further details on the historical analysis, I argue, will be useful to enhance the sociopolitical analysis in the future research of how the ES concept has been shaped.

The lobby among the global institutions through the environmental politics perspective has promote the general evolution of the ES concept has being shaped by the more multidisciplinary approach (Chaudhary, et.al., 2015). This promote the evidences that show a support to the wider actors involved (Fairhead, et. al., 2012, p. 239). Analysis on 


\section{Wulandari}

'Chalking Up the Benefits' Project: The Economic Valuation of Ecosystem Services...

the policy arena and the societal arena, however, shows the growing aspects beyond the useful part of the ES concept for its inclusiveness both in the national and local context. Beyond controversial farming subsidy and the negotiations around decoupling 'green payment' from the agricultural sector, there are elite capture that show similar pattern. Taking into the account around the dark green movement, I grasp a doubt onto the sincerity around the global agenda to the sustainable development using the economic valuation on the ES. The commitment among the nations could still possible implicate a 'cosmetic solution'. The close relationship between the human and the natural world has not been seen in the effort to the 'fundamental reforms of the way society is organized' (Chapin, et. al. 2009). This creates potency for the rising of the resistance into the related 'green' movement.

The growing ES concepts could possibly have a different direction if there is no motivation to the notion of materialism (Kosoy and Corbera, 2010). For example, the impact from elite capture and distributional issues arises through the growing complex institutions that involves in the environmental protection both in the developed and developing country. The effect is the loss of trust in the societal interactions and this should be an alarming rate for the varieties parties to depoliticize the 'green' using economic valuation of ecosystem services.

\section{References}

AF News Agency. (2016). Investigation: Animal Welfare Breaches in Slaughterhouses Data Set. AF News Agency, 3 November. Retrieved from: https://afnewsagency.org/2016/11/03/animal-welfare-breaches-in-slaughterhousesdata

Agyeman, J. (2001). Ethnic Minorities in Britain: Short Change Systematic Indifference and Sustainable Development. Journal of Environmental Policy and Planning, 3(1), 15-30. https://doi.org/10.1080/15239080108559291

Agyeman, J. (2002). Constructing Environmental (In) Justice: Transatlantic Tales, Environmental Politics, 11(3), 31-53. https://doi.org/10.1080/714000627

Agyeman, J. \& Evans, B. (2004). Just Sustainability: The Emerging Discourse of Environmental Justice in Britain? The Geographical Joumal, 170(2), 155-164. https://doi.org/10.1111/j.0016-7398.2004.00117.x

Agyeman, J., Bullard, R. D. \& Evans, B. (2010). Exploring the Nexus: Bringing Together Sustainability, Environmental Justice and Equity. Space and Polity, 6(1), 77-90. https://doi.org/10.1080/13562570220137907

Alcamo, J. (2003). Ecosystems and Human Well-Being: A Framework for Assessment. Island Press: Washington DC.

Appadurai, A., (2004). The Capacity to Aspire: Culture and the Terms of Recognition. In Rao, V. and Walton, M., (eds.) Culture and Public Action, Stanford University Press, Palo Alto, California, 59-84.

Armsworth, P. R., Chan, K. M. A., Daily, G. C., Ehrlich, P. R., Kremen, C., Ricketts, T. H., \& Sanjayan, M. A. (2007). Ecosystem-Service Science and The Way Forward for Conservation. Conservation Biology, 21(6), 1383-1384. https://doi.org/10.1111/j.15231739.2007.00821.x 


\section{Wulandari}

'Chalking Up the Benefits' Project: The Economic Valuation of Ecosystem Services...

Bates, S. (2008). Rebellious Town of Tom Paine and Bonfire Reveals Prints Own Bank Notes. The Guardian, 10 September. Retrieved from https://www.theguardian.com/business/2008/sep/10/currencies.britishidentity

Bozo, F. (2008). The Failure of a Grand Design: Mitterand's European Confederation, 19891991. Contemporary European History, 17(3), 391-412. Doi: https://doi.org/10.1017/s0960777308004542

Brockington, D., Duffy, R., \& Igoe, J. (2008). Nature Unbound: Conservation, Capitalism and The Future of Protected Areas. London: Earthscan.

Bruneteau, B. (2000). The construction of Europe and the concept of the nation-state. Contemporary European History, 9(2), 245-260. Doi https://doi.org/10.1017/s0960777300002046

Carton, W. (2014). Environmental Protection as Market Pathology?: Carbon Trading and the Dialectics of the "Double Movement." Environment and Planning D: Society and Space, 32(6), 1002-1018. Doi: https://doi.org/10.1068/d13038p

Chapin, et. al. (2009). Principles of Ecosystem Stewardship: Resilience-based Natural Resource Management in a Changing World. New York: Springer.

Chaplin, et. al. (2017). Developing A Measure of High Nature Value Farmland (HNVF) For the Rural Development Program England. Natural England. (NERR068). Retrieved from: http://publications.naturalengland.org.uk/publication/ 6306196997275648

Chaudhary, S., McGregor, A., Houston, D., \& Chettriet, N. (2015). The evolution of ecosystem services: A time series and discourse-centered analysis. Environmental Science \& Policy, 54, 25-34. https://doi.org/10.1016/i.envsci.2015.04.025

Costanza, R. (2003). Social Goals and the Valuation of Natural Capital. Environmental Monitoring and Assessment, 86(1-2), 19-28. https://doi.org/10.1023/a:1024045221992

Daily, G. C. (1997). Nature's Services: Societal Dependence on Natural Ecosystems. Island Press: Washington DC.

Defra. (2011). Biodiversity 2020: a strategy for England's wildlife and ecosystem services. (PB13583). Available at: https://www.gov.uk/government/publications/biodiversity2020-a-strategy-for-england-s-wildlife-and-ecosystem-services

Den Besten, J. W., Arts. B., \& Verkooijen, P. (2014). The evolution of REDD+: An analysis of discursive-institutional dynamics. Environmental Science \& Policy, 35, 40-48. https://doi.org/10.1016/j.envsci.2013.03.009

De-Smedt, A. B. (2012). Negotiating the Foundations of European Law, 1950 - 57: The Legal History of The Treaties of Paris And Rome. Contemporary European History, 21(3), 339356. https://doi.org/10.1017/s0960777312000239

Dobbs, T. L., \& Pretty, J. (2008). Case Study of Agri-Environmental Payments: The United $\begin{array}{llll}\text { Kingdom. } & \text { Ecological } & \text { Economics, } & \text { 64(4), }\end{array}$ https://doi.org/10.1016/i.ecolecon.2007.07.030

Donald, P. F., Pisano, G., Rayment, M., \& Pain, D. (2002). The Common Agricultural Policy, EU Enlargement and the Conservation of Europe's Farmland Birds. Agriculture, Ecosystems and Environment, 89(3), 167-182. https://doi.org/10.1016/s0167$\underline{8809(01) 00244-4}$

European Commission. (2017). Monitoring EU Agri-food Trade: Development until May 2017. Retrieved from: https://ec.europa.eu/agriculture/sites/agriculture/files/tradeanalysis/monitoring-agri-food-trade/2017-05 en.pdf

Fairhead, J., Leach, M. \& Scoones, I. (2012). Green grabbing: a new appropriation of nature? The Journal of Peasant Studies, 39(2), 237-261. https://doi.org/10.1080/03066150.2012.671770 


\section{Wulandari}

'Chalking Up the Benefits' Project: The Economic Valuation of Ecosystem Services...

Giauque, J. G. (2000). The United States and the Political Union of Western Europe, 1958 1963. Contemporary European History, 9(1), 93-110. https://doi.org/10.1017/s0960777300001041

Gómez-Baggethun, E., \& Ruiz-Pérez, M. (2011). Economic Valuation and The Commodification of Ecosystem Services. Progress in Physical Geography, 35(5), 613-628. https://doi.org/10.1177/0309133311421708

Gómez-Baggethun, E., Groot, D. R., Lomas, P. L., \& Montes, C. (2010). The History of Ecosystem Services in Economic Theory and Practice: From Early Notions to Markets and Payment Schemes. Ecological Economics, 69(6), 1209-1218. https://doi.org/10.1016/j.ecolecon.2009.11.007

Graugaard, J. D. (2012). A Tool for Building Community Resilience? A Case Study of The $\begin{array}{llll}\text { Lewes Pound. Local } & \text { Environment, }\end{array}$ https://doi.org/10.1080/13549839.2012.660908

Hirons, M., Comberti, C. \& Dunford, R. (2016). Valuing Cultural Ecosystem Services. The Annual Review of Environment and Resources, 41(1), 545-574. https://doi.org/10.1146/annurev-environ-110615-085831

IPES FOOD. (2016). From uniformity to diversity. (Report 02). Retrieved from: http://www.ipesfood.org/images/Reports/Uniformity'ToDiversity ExecSummary.pd f

Jackson, C. (1993). The First British MEPs: Styles and Strategies. Contemporary European History, 2(2), 169-195. https://doi.org/10.1017/s0960777300000412

Kosoy, N. \& Corbera, E. (2010). Payment for Ecosystem Services as Commodity Fetishism.

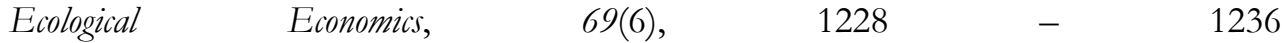
https://doi.org/10.1016/j.ecolecon.2009.11.002

Lewes Town Council. (2017). Neighborhood plan 2015 - 2033: pre-submission draft May 2017. Available at: http://www.lewes4all.uk/

Lobley, M. \& Potter, C. (1998). Environmental Stewardship in UK Agriculture: A Comparison of The Environmentally Sensitive Area Program and The Countryside Stewardship Scheme in South East England. Geoforum, 29(4), 413-432. https://doi.org/10.1016/s0016-7185(98)00019-0

Lockhart, A. (2015). Developing an Offsetting Program: Tensions, Dilemmas, And Difficulties in Biodiversity Market-Making in England. Environmental Conservation, 42(4), 335-334. https://doi.org/10.1017/s0376892915000193

Ludlow, N. P. (2005). The Making of the CAP: Towards A Historical Analysis of The EU's First Major Policy. Contemporary European History, 14(3), 347-371. https://doi.org/10.1017/s0960777305002493

Lynch, F. M. B. (2000). De Gaulle's First Veto: France The Rueff Plan and The Free Trade Area. Contemporary European History, 111-135. https://doi.org/10.1017/s0960777300001053

McCauley, D. J. (2006). Selling out on nature. Nature, 7 September. Retrieved from: http://www.nature.com/nature/journal/v443/n7107/full/443027a.html? foxtrotcallb ack=true

Mendelsohn, R. \& Olmstead, S. (2009). The Economic Valuation of Environmental Amenities and Disamenities: Methods and Applications. The Annual Review of Environmental and Resources, 34(1), 325-347. https://doi.org/10.1146/annurev-environ-011509-135201

Monbiot, G. (2013). Farming Subsidies: This Is the Most Blatant Transfer of Cash to The Rich. The Guardian, 1 July. Retrieved from: https://www.theguardian.com/commentisfree/2013/jul/01/farm-subsidies-blatanttransfer-of-cash-to-rich 


\section{Wulandari}

'Chalking Up the Benefits' Project: The Economic Valuation of Ecosystem Services...

Monbiot, G. (2014). Can you put a price on the beauty of natural world? The Guardian, 22 April. Retrieved from: https://www.theguardian.com/commentisfree/2014/apr/22/price-natural-worldagenda-ignores-destroys

Moore, J. (2000). Environmental Crises and The Metabolic Rift in World-Historical Perspective. Organization and Environment, 13(2), 123-157. https://doi.org/10.1177/1086026600132001

Moravcsik, A. (2000). De Gaulle Between Grain and Grandeur: The Political Economy of French EC Policy, 1958 - 1970 (Part 2). Journal of Cold War Studies, 2(3), 4-68. https://doi.org/10.1162/15203970051032192

Mosse, D. (2004). Is Good Policy Unimplementable? Reflections on The Ethnography of Aid Policy and Policy and Practice. Development and Change, 35(4), 639-671. https://doi.org/10.1111/i.0012-155x.2004.00374.x

Muir, H. (2013). 'Will IDS speak out against 'income support' for farmers?', The Guardian, 30 May. Retrieved from: https://www.theguardian.com/politics/2013/may/30/hughmuir-diary-iain-duncan-smith

Muradian, R., Corbera, E., Pascual, U., Kosoy, N., \& May, P. H. (2010). Reconciling Theory and Practice: An Alternative Conceptual Framework for Understanding Payments for Environmental Services. Ecological Economics, 69(6), 1202-1208. https://doi.org/10.1016/i.ecolecon.2009.11.006

Naeem, S., Bunker, D. E., Hector, A., Loreau, M., \& Perrings, C. (1999). Biodiversity and Ecosystem Functioning: Maintain Natural Life Support Processes. Ecological Society of America. https://doi.org/10.1093/acprof:oso/9780199547951.001.0001

Natural England. (2008). Grazing your landscape. Peterborough: Natural England. (NE55). Retrieved from: http://publications.naturalengland.org.uk/publication/42005

Norgaard, R. B. (2010). Ecosystem services: From eye-opening metaphor to complexity blinder. Ecological Economics, 69(6), 1219-1227. https://doi.org/10.1016/i.ecolecon.2009.11.009

Patel, K. K. (2013). Provincialising European Union: Co-Operation and Integration in Europe In A Historical Perspective. Contemporary European History, 22(4), 649-673. https://doi.org/10.1017/s0960777313000404

Plerson, J. (2017). Animal agriculture's environmental impact is still being ignored. HuffPost The Blog, 4 June. Retrieved from: http://www.huffingtonpost.co.uk/jimmypierson/animal-agriculture-environmental-impact b 10276250.html

Porter, J., et. al. (2014). Ecosystem approach handbook. Manchester: Countryscape. Retrieved from: $\quad$ http://ecosystemsknowledge.net/sites/default/files/wpcontent/uploads/2016/1/ecosystem-approach-handbook.pdf

Robert Costanza, R., d'Arge, R., Groot, R. D., Farberk, S., Grasso, M., Hannon, B., Limburg, K., Shahid Naeem, S., O’Neill, R. V., Paruelo, J., Raskin, R. G., Suttonkk, P., \& Belt, M. V. D. (1997). The Value of The World's Ecosystem Services and Natural Capital. Nature, 387(6630), 253-259. https://doi.org/10.1038/387253a0

Rogers, R., A. (1998). Overcoming the objectification of nature in constitutive theories: Toward a transhuman, materialist theory of communication. Western Journal of Communication, 62(3), 244-272. https://doi.org/10.1080/10570319809374610

Schaad, M. (1998). Plan G - A 'Counterblast'? British Policy Towards the Messina Countries, 1956. Contemporary European History, 7(1), 39-60. https://doi.org/10.1017/s0960777300004756

Schenk, C. (2002). Sterling, International Monetary Reform and Britain's Applications to Join the European Economic Community in the 1960s. Contemporary European History, 11(3), 345-369. https://doi.org/10.1017/s0960777302003016 


\section{Wulandari}

'Chalking Up the Benefits' Project: The Economic Valuation of Ecosystem Services...

Sharp, L. \& Richardson, T. (2001). Reflections on Foucauldian Discourse Analysis in Planning and Environmental Research. Journal of Environmental Policy and Planning, 3(3), 193-210. https://doi.org/10.1002/jepp.88

Simpson, J. \& Speake, J. (ed.). (2009). The Oxford dictionary of proverbs. Oxford University Press (5 ed.). Retrieved from: http://www.oxfordreference.com/view/10.1093/acref/9780199539536.001.0001/acr ef-9780199539536-e-2178? rskey=Y9Qplt\&result=934\&q

Steinfeld, et. al. (2006). Livestock's Long Shadow: Environmental Issues and Options. LEAD - FAO. Retrieved from: http://www.fao.org/docrep/010/a0701e/a0701e00.HTM

Sullivan, S. (2012). Banking Nature? The Spectacular Financialization Of Environmental Conservation. Antipode, 45(1), 198 - 217. https://doi.org/10.1111/i.14678330.2012.00989.x

Taylor, D. E. (2000). The Rise off The Environmental Justice Paradigm: Injustice Framing the Social Construction of Environmental Discourses. American Behavioral Scientist, 43(4), 508-580. https://doi.org/10.1177/0002764200043004003

Theobald, J. (2000). Overgrazing Has Stripped the Land. The Guardian, 15 November. Retrieved

from: https://www.theguardian.com/society/2000/nov/15/guardiansocietysupplement8

Tingle, C. (2015). $\mathrm{n}$ plan film master. Retrieved from: https://www.youtube.com/watch?v = qmZsk97IUfQ

Transition Town Lewes. (2011). What Does the Local Environment Do for Lewes's Economy? Retrieved from: https://www.transitiontownlewes.org/love workshop april.html

Tsing, A. L. (2005). An Ethnography of Global Connection. Princeton: Princeton University Press.

Vatn, A. (2002). Multifunctional Agriculture: Some Consequences for International Trade Regimes. European Review of Agricultural Economics, 29(3), 309-327. https://doi.org/10.1093/eurrag/29.3.309

Vatn, A. (2010). An Institutional Analysis of Payments for Environmental Services. Ecological Economics, 69(6), 1245-1252. https://doi.org/10.1016/j.ecolecon.2009.11.018

Vidal, J. (2011). Environment White Paper Unveils Plans for England's 'Natural Assets'. The Guardian, 7 June. Retrieved from: https://www.theguardian.com/environment/2011/jun/07/environment-white-paper

Warlouzet, L. (2011). De Gaulle As A Father of Europe: The Unpredictability of The FTA's Failure and The EEC's Success (1956-58). Contemporary European History, 20(4), 419-434. https://doi.org/10.1017/s0960777311000464

Westman, W. (1977). How Much Are Nature's Services Worth? Science, 197(4307), 960-964. https://doi.org/10.1126/science.197.4307.960

Woodland, M. \& Acott, T. G. (2007). Sustainability and Local Tourism Branding in England's South Downs. Journal of Sustainable Tourism, 15(6), 715-734. https://doi.org/10.2167/jost652.0 